\title{
Technical and economic feasibility of biodiesel production by family farmers
}

\author{
Augustinho Borsoi ${ }^{1 \star}$, Reginaldo Ferreira Santos ${ }^{1}$, Carlos Eduardo Camargo Nogueira ${ }^{1}$, \\ Deonir Secco ${ }^{1}$, Marco Antônio Abreu de Andrade ${ }^{2}$, Paulo Ricardo Lima ${ }^{3}$ and \\ Poliana Ferreira da Costa ${ }^{3}$
}

${ }^{1}$ Post-Graduate Programs Masters in Energy in Agricultural - Universidade Estadual do Oeste do Paraná - UNIOESTE. Rua Universitária, 2069, CEP: 85.819-130, Bairro Faculdade, Cascavel/PR, Brazil.

${ }^{2}$ Agronomist, Instituto Paranaense de Assistência Técnica e Extensão Rural - EMATER, Corbélia/PR, Brazil.

${ }^{3}$ Post-Graduate Programs in Agronomy - Masters and Doctorate - Universidade Estadual do Oeste do Paraná UNIOESTE.Campus Marechal Cândido Rondon/PR, Brazil.

Accepted 24 September, 2013

\begin{abstract}
The study aims to assess the economic feasibility of biodiesel production in association with others by family farmers in the town of Corbélia/PR. Biodiesel is presented as a partial alternative to socioeconomic and environmental oil or total replacement of diesel oil, thus requiring studies on its economic viability. The work was developed through a case study to verify the economic feasibility of installing a biodiesel plant with other associations by family farmers. The raw materials used for oil extraction were soybean, sunflower and canola, depending on the meal being used in animal nutrition. Cash flows were developed, with the costs and revenues before and after installation of the project. From the cash flow, Net Present Value (NPV), internal rate of return (IRR) and payback period of capital (payback) were calculated. The IRR of the project was $49 \%$, the NPV was US $\$ 32,283,35$ and payback was 2.03 years. The combined production of biodiesel presented economic viability with interaction between the activities of the property.
\end{abstract}

Key words: Association, farmers, bio-energy.

\section{INTRODUCTION}

The use of oils and fats of vegetable or animal origin as a fuel dates back to the late nineteenth century, when Rudolph Diesel, inventor of the internal combustion engine (named after him), used crude and peanut oil in his essays. Since then, the burning of fossil fuels is altering the global climate due to increasing emissions of carbon dioxide that contribute to the warming of the atmosphere (Mota et al., 2009). It contributes to social development, especially in less developed countries; it also creates job as well as income distribution in the field by use of different oil species for oil production (Mothé et al., 2005; Rivaldi et al., 2008).

Currently, there is a diversity of plants that can be used to obtain oil for biodiesel production. Among them are sunflower oil (42\%) with yield of $1600 \mathrm{~kg} \mathrm{ha}^{-1}$ and canola and crambe oil (38\%) with yield of 1800 and $1200 \mathrm{~kg} \mathrm{ha}^{-1}$, respectively. Soybeans have on average $18 \%$ oil from grains and yield of $2600 \mathrm{~kg} \mathrm{ha}^{-1}$; it is the crop most used for biodiesel production in Brazil (Santos et al., 2008). During the extraction process of vegetable oil for 
biodiesel production, excellent pies are obtained for the feeding of dairy cattle (Bomfim et al., 2009).

Chain milk is important economically and socially in agribusiness; it generates income and engages a number of people and a large number of institutions, companies and organizations throughout its organizational structure. The milk has many properties (Kirchner, 2009). The milk chain is developed mainly in small farms, called the family farm, which is defined according to Law $\mathrm{n}^{\circ}$. 11,326, as farms with properties less than four fiscal modules, use family labor, their income predominantly originates from family business activities and their property is managed by family members (Brazil, 2006). If the farmer fails to work individually and begin to form partnerships, through associations and cooperatives, it has mechanisms to reduce economic inequality in the rural environment (Moos, 2005).

Production chain of biodiesel is somewhat complex, requiring consistent recommended techniques for implantation (Roberts et al., 2007). Secondary products (pies, bran, glycerin and food) originate in the biodiesel supply chain, and the correct disposal of these products or getting good prices, affects the viability of biodiesel as they become a capital (Borges, 2008). The economic analysis of an activity is essential to adjust its production process to the reality of agriculture. To know the feasibility of a project, some methods are used, including the Net Present Value (NPV), internal rate of return (IRR), payback period (known in Portuguese as payback or capital recovery period); these three are the most used (Rodrigues et al., 2007).

Activity would be desirable if the NPV is positive, which means paying the interest rate used. Therefore, one must bring the values of each time period to the current value of both investments and costs and revenues (Rodrigues et al., 2007).

The IRR of a project, also called the marginal efficiency of capital is the discount rate that equates the present value of future revenues to the present value of future costs of the project (Son et al., 2003). The IRR can show the cash situation of the activity and, if favorable, presents the results to cover other fixed costs, risks, return on capital and entrepreneurship (Souza et al., 2009).

In this sense, the aim of this work is to analyze the economic feasibility for the installation of a biodiesel production unit by family farmers in Brazil.

\section{METHODOLOGY}

This study was conducted through a case study (simulation) to verify the economic viability for the installation of a biodiesel production plant ( $1000 \mathrm{~L}$ day) by family farmers in Brazil.

The research was based on a study of a typical property of a family farm. The study involves all steps for the production of biodiesel from oilseed production, storage of grain, pressing of oil extraction, fate of cake resulting from the pressing and processing of oil into biodiesel. The cake resulting from oil extraction process is fed to dairy cattle and used for commercial excess. The methodology used for this study was that of Canziani (2007), which divides the economic analysis of a project in stages: diagnosis, market research, engineering design and evaluation, as described as follows.

\section{Diagnosis}

The long-term viability of a company includes an evaluation of the profitability of activities as well as their economic, environmental and political activities. At this stage of diagnosis, one should make an analysis of the total production cost, which includes compensation for all factors of production, considering variable and fixed costs.

Data for diagnosis were obtained through structured interviews with technicians in the municipal office of the PR-EMATER Corby. For the study, we used a typical familiar property that produces milk and grains for their own consumption and sales of surplus.

\section{Market study}

The study involves marketing the product or service produced; it is one of the factors of production needed for this production process. In the study of factor of production, markets seeks to: identify the availability of goods and services required by the project, identify existing marketing channels, analyze the behavior of factor prices, based on trend and seasonality and any other information for estimating the expected prices of these factors on the horizon of the project.

In this study, three oilseeds, soybean, sunflower and canola will be worked on mainly due to the possibility of using the cake resulting from the extraction of oil in the diet of dairy cattle; it is very important for interaction in family farming and this culture has its production technology widespread and is highly studied. For using such oil, it was determined that it would take 35 properties with an average area of 20.36 ha for cultivation (total of 677.6 ha) to supply the plant during the year.

Information on the cost of production of oil was obtained from the IAPAR (Agronomic Institute of Paraná), EMATER-PR (Paraná Institute of Technical Assistance and Rural Extension) and agricultural enterprises of the region; prices of raw materials and marketing end products (biodiesel, pie, glycerin, milk) were defined based on regional and market research companies specializing in such products.

\section{Design engineering}

The market research combined with design engineering to generate cash flow of the company with the project, which contains the values of investment, revenue, operating cost, and finally the balance or net inflows of the project in time. In fact, the surest way to produce cash flows of projects is to do it in three steps. In the first draw up cash flow of the property without the proposed investment, and data on value of assets, revenues and expenses (cash) coming from the diagnostic company. The second is the cash flow of the property with the proposed investment in the project, with the income and expenses after the project implementation. The third step is to generate the project cash flow, this being the difference between the cash flow after and before the project.

The process for the production of biodiesel transesterification has been chosen; it is the method mostly used at the time of its lower cost and with ease. The process utilizes an alcohol, in case of methanol, to react with the vegetable oil in the presence of a catalyst (sodium hydroxide $-\mathrm{NaOH}$ ) for separating glycerol from the oil, producing biodiesel. In engineering of the project costs to 
Table 1. Scheme of the crop rotation for the oilseeds production.

\begin{tabular}{clllclclc}
\hline \multirow{2}{*}{ Year } & Summer & \multicolumn{7}{c}{ Winter } \\
\cline { 2 - 8 } & Culture & ha & Culture & ha & Culture & ha & Culture & ha \\
\hline 1 & Soybean & 8.47 & Corn & 8.47 & Oat & 8.47 & Canola & 8.47 \\
2 & Corn & 8.47 & Soybean & 8.47 & Sunflower & 8.47 & Oat & 8.47 \\
3 & Soybean & 8.47 & Corn & 8.47 & Oat & 8.47 & Canola & 8.47 \\
4 & Corn & 8.47 & Soybean & 8.47 & Sunflower & 8.47 & Oat & 8.47 \\
5 & Soybean & 8.47 & Corn & 8.47 & Oat & 8.47 & Canola & 8.47 \\
6 & Corn & 8.47 & Soybean & 8.47 & Sunflower & 8.47 & Oat & 8.47 \\
7 & Soybean & 8.47 & Corn & 8.47 & Oat & 8.47 & Canola & 8.47 \\
8 & Corn & 8.47 & Soybean & 8.47 & Sunflower & 8.47 & Oat & 8.47 \\
9 & Soybean & 8.47 & Corn & 8.47 & Oat & 8.47 & Canola & 8.47 \\
10 & Corn & 8.47 & Soybean & 8.47 & Sunflower & 8.47 & Oat & 8.47 \\
\hline
\end{tabular}

storage of grain, pressing plant for production of biodiesel, as well as the costs of all supplies and services used in their production were calculated. The production costs of biodiesel were obtained through interviews in companies, government agencies and of the Assis Gurgacz Faculty Farm, which has a mini-plant for the production of biodiesel and companies in the region. With these data it was possible to generate the cash flow of the project for further economic evaluation.

To obtain the raw material for biodiesel production were considered three oilseed crops: soybean, canola and sunflower. These crops adapt to the region where you deploy the project and allow a scheme of crop rotation (Table 1), seeking to give sustainability to the project.

Production of oilseeds in the agricultural area used for planting (16.94 ha) would be divided into two smaller plots of 8.47 ha each; they are used for cultivating a crop of summer oilseed and corn for crop rotation and also animal feed. In winter, there are oat and oilseed (sunflower or canola).

In the process of oil extraction, the following values of oil content in grains were considered: $18 \%$ for soybeans; $35 \%$ for sunflower; and $32 \%$ for canola. As for the pie production values, the followings were considered: 55,80 and $65 \%$ for soybean, sunflower and canola, respectively.

\section{Project evaluation}

The project evaluation is elaborated on different aspects such as economic viability analysis performed from the values of cash flows of the project through various criteria and financial evaluation. This is used to identify if the net cumulative balance of the project is positive over time.

Analysis of economic feasibility study was carried out using economic indicators such as NPV, which takes into account the effect of time on the monetary values, using the average interest rate of $6 \%$ (Interest Rate Term - TJLP) (Receita Federal Brasil, 2011); the IRR which raises the total interest that is earned on capital, i.e the interest rate, NPV is equal to 0 and payback, which shows the time required to raise investment. In this study, we used the simple payback that does not take into consideration an interest rate applied on outstanding annual cash flow.

We used the balances of cash flow for nine years, discounting the last year. It has the return of the residual value of goods and machinery. The calculations were performed for economic analysis in a spreadsheet, through which were inserted all diagnostic information, market research and engineering design, enabling the attainment of economic analysis.

\section{RESULTS AND DISCUSSION}

Featuring a typical property of the City of Corby, we have the production of each holding property. Table 2 shows all the activities on the property, with its productivity and total production during the year. These data represent the average of recent years' family farmers that will be part of the project.

Table 2 presents the activities on the property prior to project implementation. The cultivation of soybeans, corn and wheat yields 27,$104 ; 67,760$ and $20,328 \mathrm{~kg} /$ year $^{-1}$, respectively. The dairy cattle have an annual production of $59,475 \mathrm{~L}$, with a productivity of $13 \mathrm{~L}$ cow/day, and diet of the animals in the commercial feed is supplied at the rate of $1 \mathrm{~kg}$ of feed for every 2 liters of milk produced.

After implementation of the project some changes in the production system will be performed, such as the introduction of the planting of oilseeds for oil production. The investment in improvements, machinery, equipment and hiring of permanent labor will be acquired through association among farmers. With the implementation of the project, the area planted with winter wheat is now grown with an oilseed crop to produce oil (canola or sunflower), in an area of 8.47 ha (Table 3 ).

A seen in Table 3, activities would be conducted on the property after the project implementation. The dairy cattle productivity may increase due to the cake those results from oil extraction. The process of extracting the oil is cold, without cooking and using solvent; the pie preserves a higher contents of proteins and lipids, which give a higher quality than conventional meal. In this study, the same productivity was kept.

As can be seen in Table 2, there was the introduction of canola crop and sunflower seeds on the property with the purpose of obtaining oil for biodiesel production and production quality cake for animal feed. There was a $30 \%$ replacement of the concentrate used in animal feed, for the different oil cake.

The project for implementation of the biodiesel plant involves the following stages: production, storage, 
Table 2. Activities undertaken on the property before the project.

\begin{tabular}{lcll}
\hline Activity & Area (ha) & Productivity & Production \\
\hline Milk & $3.42^{*}$ & $13 \mathrm{~L} \mathrm{cow} /$ day $^{-1}$ & $59,475 \mathrm{~L} \mathrm{year}^{-1}$ \\
Soybean & 8.47 & $3,200 \mathrm{~kg} \mathrm{ha}^{-1}$ & $27,104 \mathrm{~kg} \mathrm{year}^{-1}$ \\
Corn & 8.47 & $8,000 \mathrm{~kg} \mathrm{ha}^{-1}$ & $67,760 \mathrm{~kg} \mathrm{year}^{-1}$ \\
Wheat & 8.47 & $2,400 \mathrm{~kg} \mathrm{ha}^{-1}$ & $20,328 \mathrm{~kg} \mathrm{year}^{-1}$ \\
\hline
\end{tabular}

${ }^{*}$ Area only with dairy cattle grazing in winter has 8.47 ha of oats. ** Production of milk in 305 days of year and 15 cows in lactation.

Table 3. Activities to develop property with the implementation of the project.

\begin{tabular}{lcllccc}
\hline Activity & Area (ha) & Productivity & Production & $\begin{array}{c}\text { Oil content } \\
(\%)\end{array}$ & $\begin{array}{c}\text { Oil production } \\
\left(\text { kg year }^{-1}\right)\end{array}$ & $\begin{array}{c}\text { Oil production } \\
\left(\mathbf{L}_{\text {year }}{ }^{-1}\right)\end{array}$ \\
\hline Milk & $3.42^{*}$ & $13 \mathrm{~L} \mathrm{cow} / \mathrm{day}^{* *}$ & $59.475 \mathrm{~L} \mathrm{year}^{-1}$ & - & - & - \\
Soybean & 8.47 & $3.200 \mathrm{~kg} \mathrm{ha}^{-1}$ & $27.104 \mathrm{~kg} \mathrm{year}^{-1}$ & 18 & 4542,088 & $4,878.72$ \\
Corn & 8.47 & $8.000 \mathrm{~kg} \mathrm{ha}^{-1}$ & $67.760 \mathrm{~kg} \mathrm{year}^{-1}$ & - & - & - \\
Sunflower & 8.47 & $1.700 \mathrm{~kg} \mathrm{ha}^{-1}$ & $14.399 \mathrm{~kg} \mathrm{year}^{-1}$ & 40 & 5275,794 & $5,759.60$ \\
Canola & 8.47 & $2.200 \mathrm{~kg} \mathrm{ha}^{-1}$ & $18.634 \mathrm{~kg} \mathrm{year}^{-1}$ & 35 & 5954,495 & $6,521.90$ \\
\hline
\end{tabular}

${ }^{*}$ Area only with dairy cattle grazing in the winter has 8.47 ha of oats. ${ }^{* *}$ Production of milk in 305 days of year and 15 cows in lactation. Density of soybean oil: $0.931 \mathrm{~g} \mathrm{~cm}^{3}$; sunflower $0.916 \mathrm{~g} \mathrm{~cm}^{3}$ and canola: $0.913 \mathrm{~g} \mathrm{~cm}^{3}$.

Table 4. Budget of goods and services for deployment of the biodiesel plant.

\begin{tabular}{lc}
\hline Property and services & Initial value (US\$) \\
\hline Leasehold Improvements & $63,944.44$ \\
Grain storage structure & $169,301.85$ \\
Biodiesel production structure & $85,500.00$ \\
Pressing of grains & $105,000.00$ \\
Total investment & $359,801.85$ \\
Permanent labor & $14,444.44$ \\
\hline
\end{tabular}

compression of the grains, biodiesel plant (tanks for storage of vegetable oil and biodiesel, boiler, oil filtration plant and processing plant to remove the glycerin from vegetable oil). Economic analysis was carried out on budget (Table 4 ) of all necessary goods.

In Table 4, the investment on the project that can be implemented is US\$ 359,801.85; all the stages of the process are added from the storage of grain oilseeds, pressing of oil extraction and processing of vegetable oil into biodiesel at the plant. With respect to labor, technicians were hired to operate the process of extracting the oil and operating the plant with a monthly salary of US $\$ 666.66$, adding $60 \%$ of this amount to charges.

Table 5 showed the variable cost of all inputs used to convert vegetable oil by transesterification process in biodiesel, followed by the quality standards of the ANP. Taxes are calculated in relation to tax on biodiesel produced using raw materials provided by family farms. This is according to the legislation, which focuses on PIS
/ PASEP US\$ 6.93 and COFINS US\$ $31.96 \mathrm{~m}^{3}$ of biodiesel made from raw materials purchased for the family farmer framed PRONAF, resulting in US\$ 0.039 per liter of biodiesel (Brazil, 2004).

In Table 5, the cost of inputs for processing vegetable oil into biodiesel by transesterification process using methanol and $\mathrm{NaOH}$, taxes, energy, cost of pressing the raw material and water was US $\$ 0.32 \mathrm{~L}^{-1}$ of biodiesel and the total cost of labor, permanent work, depreciation of plant and machinery was US $\$ 0.62$ per liter. This cost did not discount the recovered methanol from the glycerin that can be reused, reducing the cost of litigation. The amount of water used is one liter per biodiesel. The company DEDINI (2006) had a cost of US $\$ 0.089$ per liter of biodiesel production scale of 100 million. In Table 6, we can observe the projected revenue from the implementation of the biodiesel project. Values are described in revenue from the sales of biodiesel, glycerin; and pie will not be used in animal feed.

As can be seen in Table 6, the average production of 
Table 5. Components of the production cost of biodiesel in the industry.

\begin{tabular}{lcc}
\hline Activity & $\begin{array}{c}\text { Quantity used per } \\
\text { litre oil }\end{array}$ & US\$ $\mathbf{L}^{-1}$ \\
\hline Methanol & $0.2 \mathrm{~L}$ & 0.19 \\
Catalyst & $6 \mathrm{~g}$ & 0.00 \\
Water & $1 \mathrm{~L}$ & 0.01 \\
Energy & - & 0.03 \\
Analyses & - & 0.04 \\
Grain pressing & & 0.01 \\
Taxes & - & 0.04 \\
Variable cost & & 0.32 \\
\hline
\end{tabular}

Table 6. Projected revenues from the sale of biodiesel and by products.

\begin{tabular}{|c|c|}
\hline Attribute & Value \\
\hline Biodiesel $\left(L_{\text {year }}^{-1}\right)$ & $332.477 \mathrm{~L}$ \\
\hline Number of farmers involved & 33 \\
\hline Biodiesel recipe (US\$ year $\left.{ }^{-1}\right)$ & $369,419.05$ \\
\hline Revenue from the sale of the meal (US\$ year ${ }^{-1}$ ) & $54,046.62$ \\
\hline Revenue from the sale of glycerol (US $\$$ year $^{-1}$ ) & $7,686.53$ \\
\hline Project average gross revenue (US\$ year ${ }^{-1}$ ) & $431,152.19$ \\
\hline Fraction of the investment property (US\$) & $10,903.08$ \\
\hline Biodiesel recipe by property (US $\$$ year $^{-1}$ ) & $11,194.52$ \\
\hline Revenue from the sale of the pie by property (US $\$$ year $^{-1}$ ) & $1,637.78$ \\
\hline Revenue from the sale of property by glycerol (US $\$$ year $^{-1}$ ) & 232.93 \\
\hline Average gross revenue per property (US $\$$ year $^{-1}$ ) & $13,065.22$ \\
\hline
\end{tabular}

$332,477 \mathrm{~L}$ of biodiesel per year was sold at US\$1,111 L 1 , whereas the average price of diesel oil during the year 2009 , according to the ANP (2009), results in an average annual revenue of US $\$ 369,419.05$. Adding the revenue from the sales of the pie that was left of the balance of the feed and glycerol (US\$ 54,046.62 and US\$ 7,686.53) respectively, the project has a total revenue of US\$ 431,152.19.

Given a typical property of 16.84 ha, the project would require 33 members to produce enough raw materials to meet the demand of oil of the plant, which is $1000 \mathrm{~L}$ day ${ }^{1}$, so that in each property will be invested US $\$ 10,903.08$ and will have a gross income average of US $\$ 11,194.52$ from the sales of biodiesel; adding the sales of pie and glycerin (US\$1,637.78 and US\$232.93) respectively will lead to a total average gross revenues of US $\$ 13,065.22$ per year during the 10 years of the project.

Cash flow of the project (Figure 1) describes the annual balances of the project; the values are obtained by subtracting the revenues from costs after the implementation of the project, indicating profitability during its lifetime.

As can be seen in Figure 1, the cash flows of the project were positive for 10 years of the study period.
Year 0 is the initial investment for property of US\$ $11,491.52$. In 10 years we have a surplus of US\$ $9,606.77$ because the sum of the residual value of the assets of the project was added to the value of revenues.

The horizon of the project has a variation in cash flow due to rotation of used oil in oil production. In years 1,3 , 5, 7 and 9, soybeans and canola were cultivated, resulting in a net cash flow of US\$6,301.08. In years 2 , 4, 6, 8 and 10, soybean and sunflower oils were cultivated, resulting in a remainder of US $\$ 4,858.88$. This result is lower with soybean and sunflower because of lower production in relation to canola. The average balance of 10 years of the project, excluding the year 0 , represents the investment, which is the sum of the residual value of the property (US\$5,660.10).

Table 7 presents the results of the evaluation of the economic project, with viability indicators -IRR, NPV and Simple Payback. These indicators serve as a benchmark for assessing whether a project has economic viability.

Looking at Table 7, it appears that the project had an IRR of $49 \%$. This figure tells us that the project will be viable only with an equal or superior hurdle rate. The NPV of US $\$ 32,383.39$ shows the feasibility of the project is a positive value, indicating long-term viability for the 


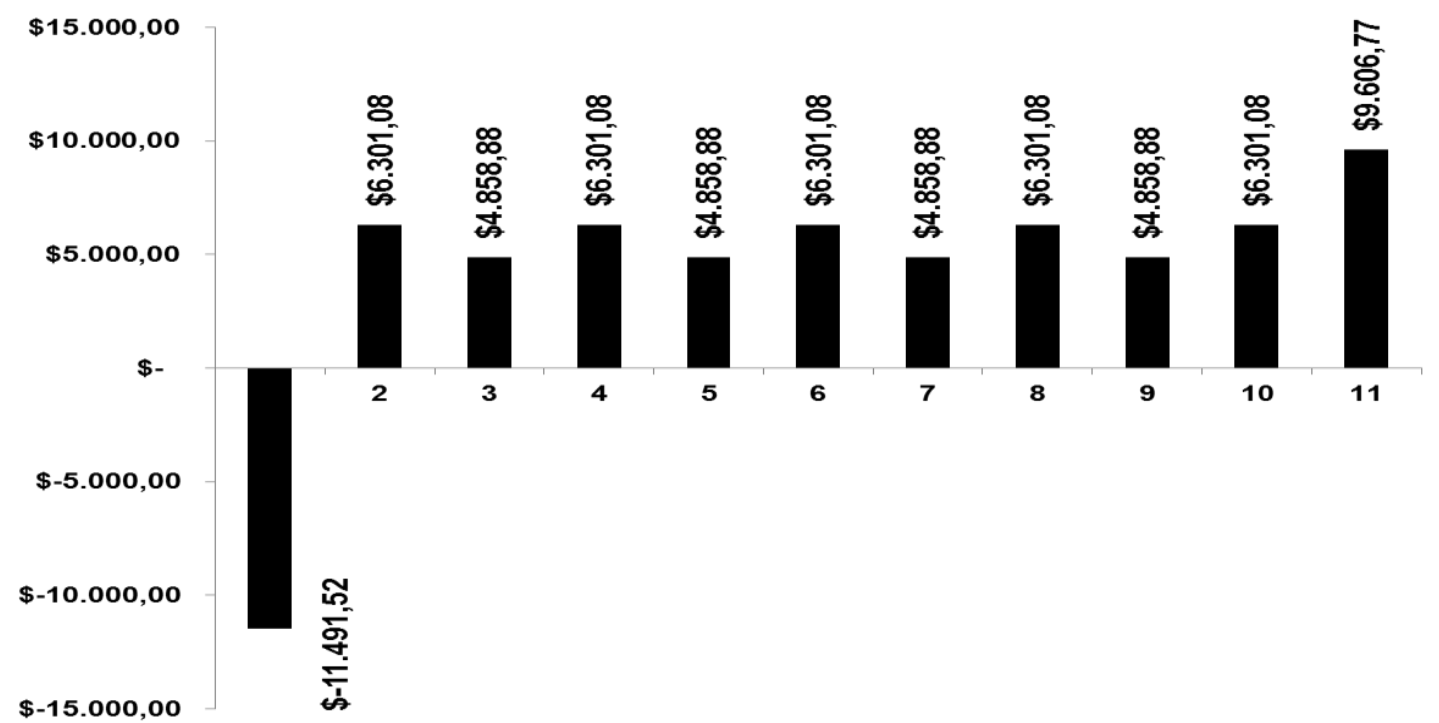

Figure 1. Diagram of cash flow per property during the 10 year project life.

Table 7. Economic indicators project.

\begin{tabular}{lccc}
\hline Indicator & IRR (\%) & VPL (US\$) & Payback (years) \\
\hline Biodiesel & $49 \%$ & US\$ 32,383.39 & 2,03 \\
\hline $\begin{array}{l}\text { NPV, Net Present Value; } \\
\text { capital. }\end{array}$
\end{tabular}

project. But the payback period for recovering the capital invested in the project for each property is 2.03 years; with the horizon of the project 10 years payback is considered low because you can recover capital in a short period of time.

In a study performed by Pereira (2009), the production of biodiesel associative form of small farmers was evaluated. By using a plant with a capacity of 5000 liters/day, biodiesel, feed and soya lecithin were produced. The raw material used was soybean. The NPV for biodiesel was US\$1,183.33 and IRR was 17 and $50 \%$ of the working capacity of the industry. The study also indicates that the production of biodiesel is not only generating the most revenue, that accounts for $16 \%$ of the revenue of the project, with only one link in the chain; it depends on the feed mill that is viable. The project has an IRR of $6.3 \%$ and NPV of US\$ 425.00 , indicating viability, because the rate of average attractiveness (TMA) is $5 \%$.

\section{Conclusion}

The production of biodiesel has economic viability, when handled in association with the family farm.

The production of biodiesel alone is not sufficient to change the reality of small farms, but its association with other holdings may facilitate its production. The dairy cattle and the production of biodiesel represent a very important union to make the project viable.

The problem of biodiesel viability is marketing barriers due to monopoly of the product. Only large groups have competitiveness in market, leaving small farmers as producers of raw materials, thus failing to participate in the process of industrialization.

\section{ACKNOWLEDGEMENT}

The first author thanks the Coordination for the Improvement Training (CAPES) for the graduate students' stipend granted.

\section{REFERENCES}

ANP - Agencia Nacional do Petróleo (2009). Síntese dos Preços Praticados - $\quad$ Brasil. Available in <http://www.anp.gov.br/preco/prc/Resumo_Mensal_Combustiveis.as p> Accessed in: 20 set. 2009.

Bomfim MAD, Silva MMC, Santos SF (2009). Potencialidades da utilização de subprodutos da indústria de biodiesel na alimentação de caprinos e ovinos. Tecnologia \& Ciência Agropecuária 3(4):15-26.

Borges MC (2008). Protótipo de um sistema integrado de apoio à 
decisão sobre investimentos industriais e agrícolas na cadeia produtiva do biodiesel. 2008. Dissertação (Mestrado em Ciência e Tecnologia de Alimentos) - Programa de Pós-Graduação em Ciência e Tecnologia de Alimentos, Universidade Federal de Viçosa, Viçosa.

Brasil (2004). Decreto $n^{\circ} 5.297$, de 6 de Dezembro de 2004. Dispõe sobre os coeficientes de redução das alíquotas da contribuição para - PIS/PASEP e da COFINS incidentes na produção e na comercialização de biodiesel, sobre os termos e as condições para a utilização das alíquotas diferenciadas, e dá outras providências. Brasília, 6 de Dezembro de 2004. Available in: <http://www.biodiesel.gov.br/docs/decreto_5.297_6dez2004.pdf. Accessed in: 20 out. 2010.

BRASIL (2006). Lei oㅜ 11.326, de 24 de julho de 2006. Estabelece as diretrizes para a formulação da Política Nacional da Agricultura Familiar e Empreendimentos Familiares Rurais. Brasília: Diário official.

Canziani JR (2007). Elaboração e análise de projetos. Curitiba: UFPR.Dedini- Indústria de Base (2006). Apresentação do Seminário: Investimentos em Biodiesel. Available in: <http://www.bndes.gov.br/conhecimento/seminario/Biodiesel_DE DINI.pdf>. Accessed in: 23 maio 2010.

Kirchner R (2009). Rumos e horizonte da Cadeia Leite no sudoeste do PR. O Presente Rural, Paraná, 21 Maio. 2009. Available in: $<$ http://www.opresenterural.com.br/noticias.p- $h p ? n=839>$. Accessed in: 12 abr. 2010.

Mota CIA, Silva CXA, Gonçalves VLC (2009). Gliceroquímica: novos produtos e processos a partir da glicerina de produção de biodiesel. Química Nova 32(3):639-648.

Mothé CG, Correia DZ, Castro BCS, Caitano M (2005). Otimização da produção de biodiesel a partir de óleo de mamona. Revista Analytica 19:27-35.
Pereira TCG (2009). Aspectos Econômicos e Financeiros do Projeto Paraná Biodiesel. In: $4^{\circ}$ Congresso Internacional De Bioenergia; $1^{\circ}$ Congresso Brasileiro De Geração Distribuída $\mathrm{E}$ Energias Renováveis, 18 a 21, 2009, Curitiba. Anais... Curitiba: UFPR.

Receita Federal Do Brasil (2011). Taxa de Juros de Longo Prazo TJLP. Available $<$ http://www.receita.fazenda.gov.br/prepararlmpressao/l mprime Pagina.asp>. Accessed in: 02 march. 2011.

Rivaldi JD, Sarrouh BF, Fiorilo R, Silva SS (2008). Glicerol de biodiesel Estratégias biotecnológicas para o aproveitamento do glicerol gerado da produção de biodiesel. Biotecnologia Ciência \& Desenvolvimento. Brasília, n. 37, pp. 44-51.

Rodrigues, ER, Cullen Jr L, Beltrame TP, Moscogliato AV, Silva IC (2007). Avaliação econômica de sistemas agroflorestais implantados para recuperação de reserva legal no pontal do Paranapanema, São Paulo. Revista Árvore, Viçosa, v.31, n.5, pp. 941-948. 